九州大学学術情報リポジトリ

Kyushu University Institutional Repository

SURVIVORSHIP AND OTHER FACTORS RELATING TO POPULATION FLUCTUATIONS OF THE PINE NEEDLE GALL MIDGE, THECODIPLOSIS JAPOIVENSIS (DIPTERA, CECIDOMYIIDAE)

Lee, Buom Youno

Miura, Tadashi

Hirashima, Yoshihiro

https://doi.org/10.5109/2479

出版情報: ESAKIA. 23，pp.119-130，1985-11-30. Entomological Laboratory，Faculty of Agriculture, Kyushu University

バージョン :

権利関係 : 


\title{
SURVIVORSHIP AND OTHER FACTORS RELATING TO POPULATION FLUCTUATIONS OF THE PINE NEEDLE GALL MIDGE, THECODIPLOSIS JAPONENSIS (DIPTERA, CECIDOMYIIDAE) ${ }^{1 / 2) 3)}$
}

\author{
BuOM Y OUNG LEE \\ Department of Forest Entomology and Pathology, \\ Forest Research Institute, Seoul 131, Korea \\ Tadashi MiUra \\ Laboratory of Insect Management, Faculty of Agriculture, \\ Shimane University, Matsue, Shimane 690, Japan \\ and \\ YoshiHIRO HiRASHIMA \\ Entomological Laboratory, Faculty of Agriculture, \\ Kyushu University, Fukuoka 812, Japan
}

\begin{abstract}
Comparative studies of the population dynamics of the pine gall midge, Thecodiplosis japonensis, were made in four Korean red pine forests. Survivorship curves developed from these studies indicate that most gall midge mortality occurs in three periods of the larval stage : 1) in newly hatched larvae, prior to gall formation, 2) in young larvae, after the galls have formed, and 3) in mature larvae that have dropped to the soil. At sites where midge populations were decreasing following a period of severe damage, mortality rates were much higher in all developmental stages than at sites with increasing populations. Examples of density-dependent mortality which can combine to suppress populations or stabilize them are : mortality of newly hatched larvae induced by physiological changes of needles resulting from severe midge damage ; larval mortality resulting from early gall withering; and mortality caused by Platygaster matsutama, a wasp parasite that attacks the midge larvae very early but kills them after they have dropped to the soil.
\end{abstract}

1) Partly supported by a grant (1983-84) from the Japan Society for the Promotion of Science, Tokyo (Principal investigators: T. Miura and J. H. Ko).

2) Contribution from the Department of Forest Entomology and Pathology, Forest Research Institute, Seoul, Korea.

3) Contribution from the Entomological Laboratory, Faculty of Agriculture, Kyushu University, Fukuoka (Ser. 3, No. 192). 


\section{Introduction}

By 1984 the pine needle gall midge, Thecodiplosis japonensis Uchida et Inouye had spread to all parts of the Republic of Korea except the northeastern and north-central extremities, At the frontal zone of its range expansion, midge population levels rose for about six consecutive years but decreased rapidly to low levels thereafter (Park \& Hyun, 1983).

The population dynamics of the midge has been studied in Korea (Park and Hyun, 1983) and Japan (Sone, 1980), but there have been few studies on the process of population fluctuation and the factors relating to it. Studies on population dynamics and factors related, especially on annual fluctuations in newly established populations, are fundamental for pest management. This paper describes and analyzes the annual changes in patterns of midge population density that follow its establishment at sites where it did not previously occur.

\section{Study Sites}

The study was carried out in four forests of red pine (Pinus densiflora $S$. et $Z$.) in Ch'ungch'óngnam-do (province), where the pine needle gall midge appeared recently (Fig. 1, Table 1). The following are details on these forests and their midge popula$\mathrm{t}$ ions.

I-1 : In Kwangsi-myǒn, Y esan-gun ; the midge was first detected there in 1981 and has been rapidly increasing in density year by year.

I-2 : In Pibong-myŏn, Ch'ǒngyang-gun; the midge was detected there in 1979, and damage reached peak severity in 1984.

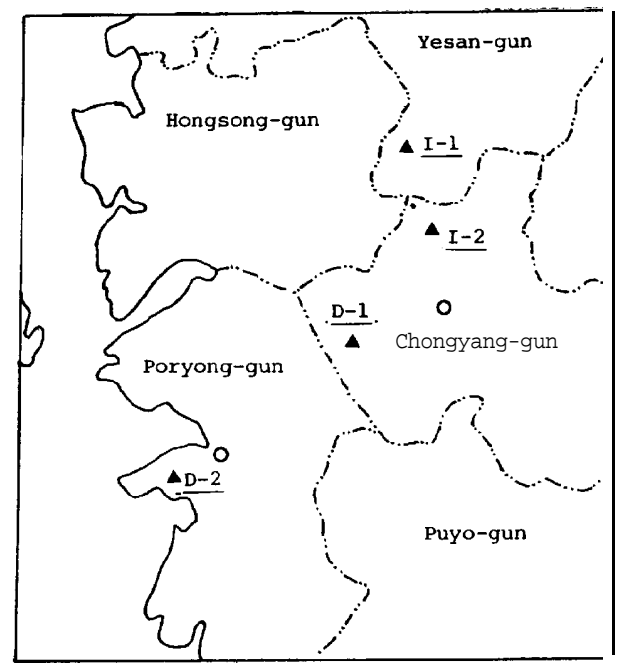

Fig. 1. Location of the study sites in Ch'ungch'bngnam-do. 
D-1 : In Hwasong-myǒn, Ch'ǒngyang-gun; the midge was first detected there in 1976, and its density began to decrease in 1984 following peak severity of damage in 1982 or 1983.

D-Z: In Taech'rn-up, Poryðng-gun; the midge population there fell to non-injurious levels after peaking several years ago.

\section{Methods}

Three $10 \times 10$ m study plots were set up at each site. In each, mean height of red pines ranged from 5 to $7 \mathrm{~m}$, and crown densities were between 0.6 and 0.8 . Each plot was divided into 16 quadrats, $2.5 \times 2.5 \mathrm{~m}$. Midge populations were sampled at three points in their development : 1) larvae in soil, 2) adults after emergence, 3) eggs and larvae on/in needles/galls. Larval densities in soil were estimated by counting numbers of larvae in 5 x $5 \mathrm{~cm}$ soil cores, the method used by Park and Hyun (1977) ; on March 1, March 18, and May 1, five core samples were collected at the center of each quadrat.

Emergence traps (Fig. 2-A) with diameters of $21.5 \mathrm{~cm}$ were used to estimate densities of emerging adults. Forty traps were placed at each study site, eight traps in one plot and sixteen in each of the other two. Counts of trapped adults were made daily from May 15 through July 15. Egg (reproductive) potential was estimated from the adult sex ratio and the size (wing length) of emerging adult females.

Survivorship of eggs on needles and larvae in galls were calculated from counts of : eggs per cluster, hatched eggs, gall formation on needles bearing eggs, live larvae in galls, and larvae killed in galls by early gall withering. Three sets of foliar samples were taken : 1) to determine the mortalities of eggs and young larvae on needles bearing eggs, six current shoots - three each from the upper and lower crown - were collected periodically from ten fixed trees in each study site, 2) to determine the population densities in tree crowns, complete counts of healthy and infested current-

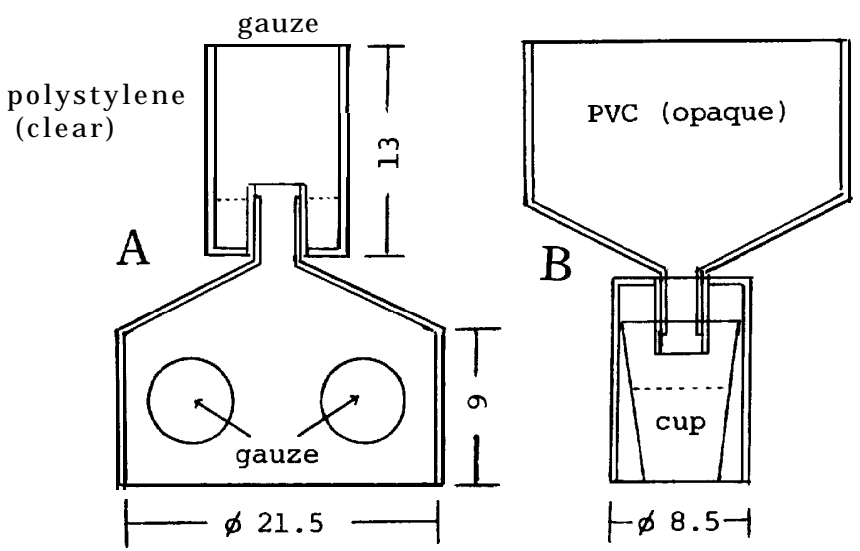

Fig. 2. Traps for emerging adults A and dropping larvae B. 
year needles were made from 20 shoots - ten from the upper halves of crowns, ten from the lower - from ten trees selected randomly in each plot (i. e. 30 per site), and 3) also from each of the latter trees, one branch was removed for determining larval mortality resulting from early gall withering.

Inverted adult emergence traps (Fig. Z-B) were used to collect samples of larvae dropping from the needles to the soil. Forty traps were set in the same positions at which adult emergence was sampled, and larvae were collected from the traps at fiveday intervals from September 25 through January 15.

For all stages, population density figures were converted to numbers per $100 \mathrm{~cm}^{2}$ of soil surface. From the density data for larvae in soil plus the mortality data for the stages in the crown, numbers per $100 \mathrm{~cm}^{2}$ of soil were computed in a retrospective manner for eggs and for larvae on/in needles.

\section{Results}

\section{Qualitative differences of individuals}

For sites with decreasing populations (D-1 \& D-Z), but not for sites with increasing ones (I-l \& I-Z), the mean size of full-grown larvae in galls tended to decrease as the number of larvae per gall increased (Fig. 3). Fig. 4 shows the size differences of individual midges and their relationship to population density (i. e. percent of current

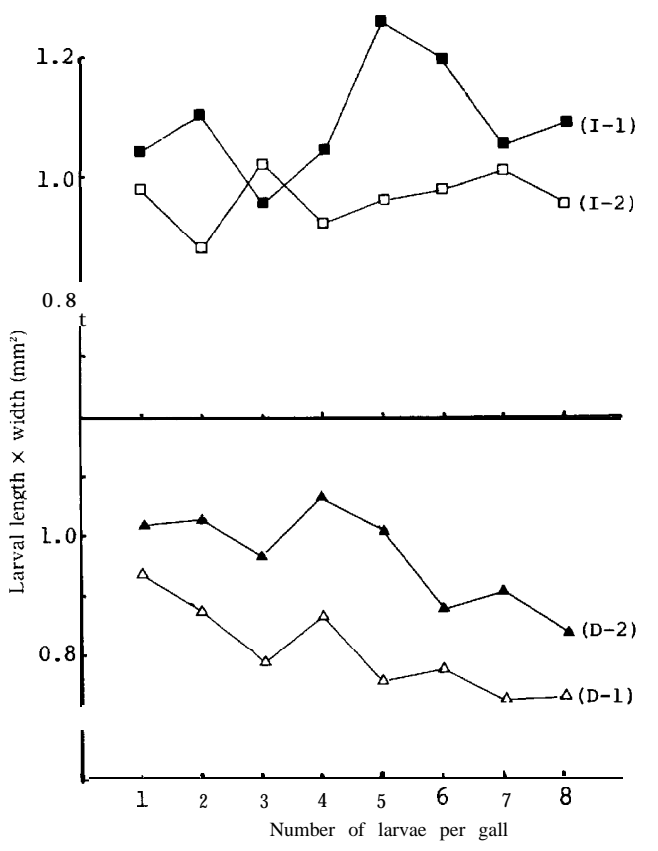

Fig. 3. Relationship between larval size and number of larvae per gall. 


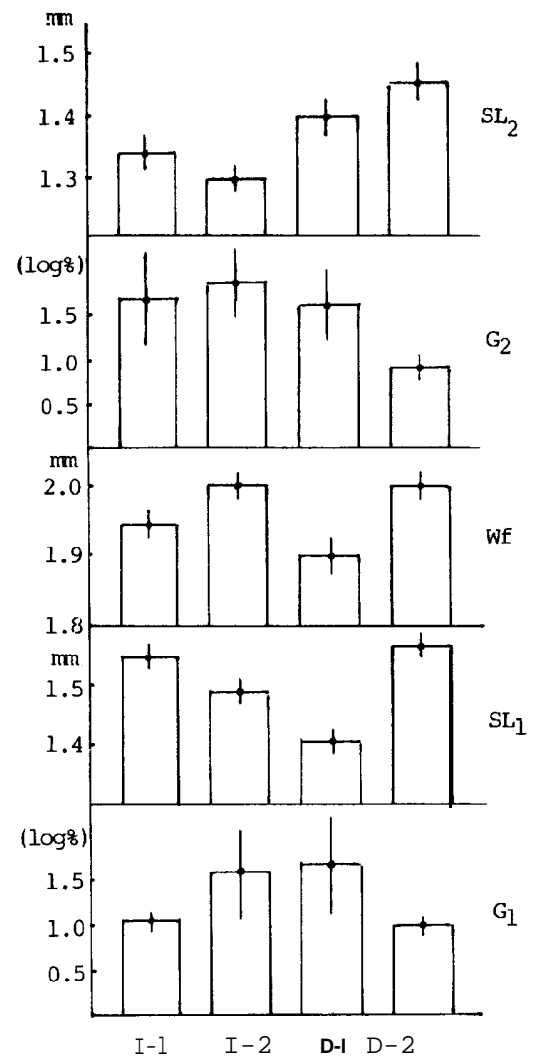

Fig. 4. Midge size and percentage of needles infested by site : length $x$ width of fully grown larvae in soil (SL1), wing length of females (Wf), length $\mathrm{x}$ width of larvae in galls (SL2), percent current needles infested in 1983 (G1) and 1984 (G2). Vertical lines indicate standard errors.



Fig. 5. Relationship between needle elongation and inter-tip distance of needle pairs. 


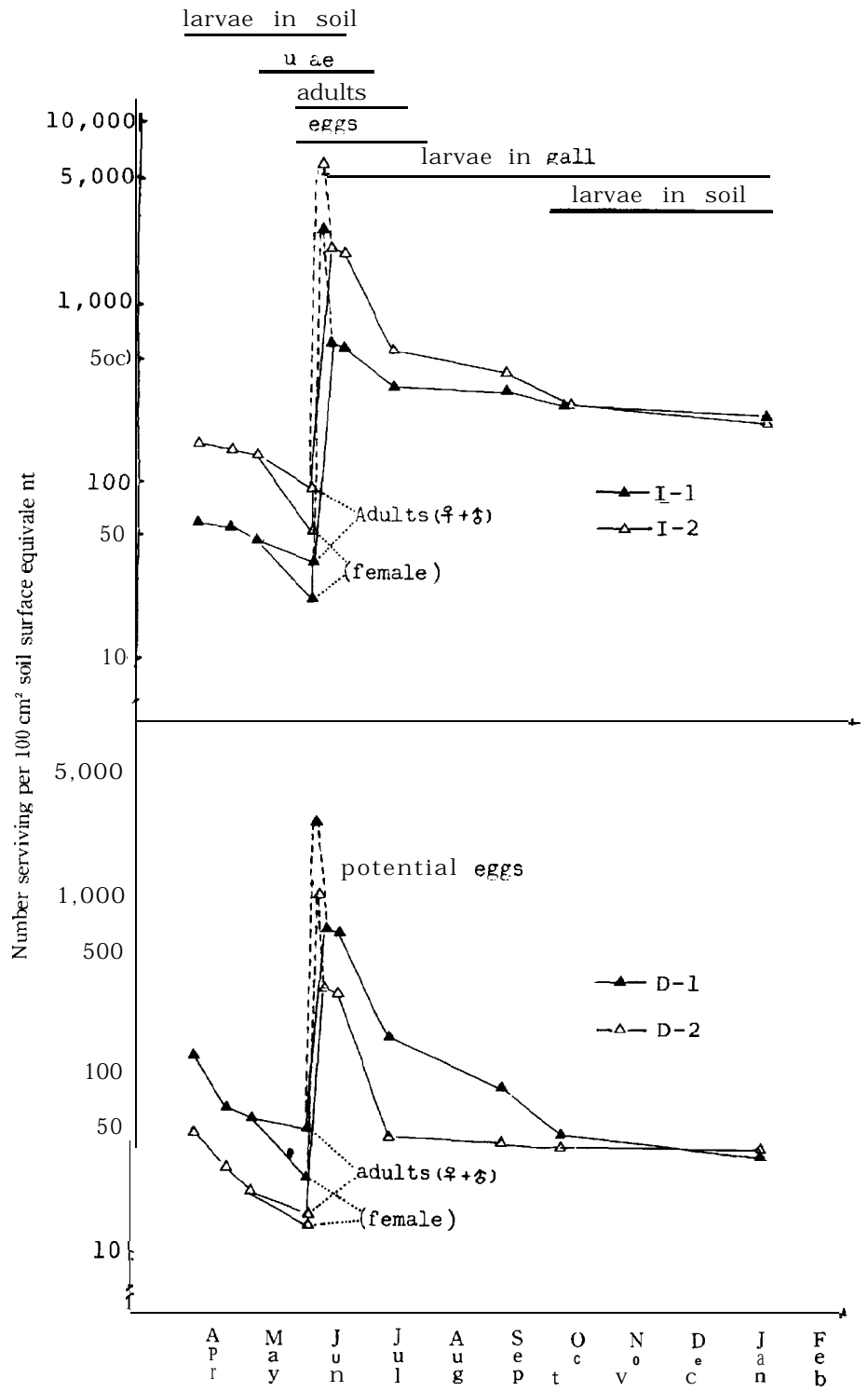

Fig. 6. Survivorship of the pine gall midge at all study sites in 1984.

Table 1. Percentages of current needles infested at each site.

\begin{tabular}{cccc}
\hline \multirow{2}{*}{$\begin{array}{l}\text { Study } \\
\text { site }\end{array}$} & $\begin{array}{l}\text { Initial } \\
\text { infestation } \\
\text { year }\end{array}$ & \multicolumn{2}{c}{ \% current needles infested } \\
\cline { 3 - 4 } & 1981 & 1983 & 1984 \\
\hline I-1 & 1979 & $11.0 \pm 0.9$ & $50.3 \pm 4.3$ \\
I -2 & 1976 & $38.7 \mathrm{t} 3.7$ & $72.3 \pm 2.6$ \\
D-I & 1975 & $54.3 \mathrm{~F} 3.8$ & $40.5 \pm 2.4$ \\
D-2 & $10.7 \pm 1.3$ & $9.2 \pm 1.1$ \\
\hline
\end{tabular}


needles infested). Mean sizes of larvae in galls and those which had overwintered in soil were smaller at sites having high population density, indicating an inverse correlation between population density and individual size. The decrease in larval size with increasing population density is believed to relate to the food shortage resulting from the poor physiological condition of the host trees.

Female/male sex ratios of adults collected in emergence traps varied among sites and were strongly correlated $(r=0.93)$ with larval size and, hence, inversely correlated with population density. At sites I-1 and I-2, where population density was increasing, at site D-2, where it was stabilized, and at site D-1, where damage was severe in the previous year, the sex ratios were $0.63,0.54,0.59$ and 0.48 , respectively.

\section{Relationship between midge mortality and pine needle physiology}

The pine needle gall midge feeds only in the larval stage, and the entire feeding period is spent within the gall at the bases of a single needle pair. Therefore, there is a strong relationship between midge survival and the physiological condition of the infested needles. Because heavy midge infestations adversely impact the physiological condition and rate of growth of the host, midge survival is adversely impacted as well. Needles that are low in vigor may be morphologically unsuitable for gall formation ; needles on which the midge larvae fail to induce gall formation are narrower and thus more flexible than needles on which galls are subsequently formed (Table 2).

There is a positive correlation between the rate of early larval mortality of the midge and the needle divergence rate in early June, the peak period of midge egg

Table 2. Size of needles on which midges successfully formed galls versus size of needles on which gall formation was unsuccessful.

\begin{tabular}{ccc}
\hline \multirow{2}{*}{ Site } & \multicolumn{2}{c}{ Width of needles* } \\
\cline { 2 - 3 } & $\begin{array}{c}\text { Gall formation } \\
\text { successful }\end{array}$ & $\begin{array}{c}\text { Gall formation } \\
\text { unsuccessful }\end{array}$ \\
\hline I - 1 & $0.98 f 0.02$ & $0.90 \pm 0.01$ \\
I -2 & $0.96 \mathrm{f} 0.01$ & $0.88 \mathrm{f} 0.01$ \\
D - 1 & $1.05 \pm 0.01$ & $0.91 \mathrm{f0.02}$ \\
D-2 & $0.98 \pm 0.01$ & $0.95 \pm 0.01$ \\
\hline
\end{tabular}

* Measured at needle mid-length in early June $(n=100)$.

Table 3. Inter-needle distance $(\mathrm{mm})$ and needle divergence rate during peak hatching period.

\begin{tabular}{lccccc}
\hline \multirow{2}{*}{$\begin{array}{l}\text { Measurement } \\
\text { position }\end{array}$} & Date & \multicolumn{4}{c}{ Site } \\
\cline { 3 - 6 } & & I-1 & I-2 & D-1 & D-2 \\
\hline \multirow{2}{*}{$\begin{array}{l}\text { June 3 } \mathrm{cm} \text { from } \\
\text { base }\end{array}$} & $\begin{array}{c}\text { June 9 } \\
\text { Per day diver- } \\
\text { gence rate }\end{array}$ & $0.47 \pm 0.04$ & $0.36 \pm 0.03$ & $0.52 \pm 0.04$ & $0.64 \pm 0.04$ \\
& $-1.5 \%$ & $-0.2 \%$ & $0.8 \%$ & $0.82 \pm 0.07$ \\
Needle tip & $\begin{array}{l}\text { June 3 } \\
\text { June 9 }\end{array}$ & $0.89 \pm 0.07$ & $0.73 \pm 0.05$ & $1.14 \pm 0.09$ & $0.89 \pm 0.06$ \\
& $\begin{array}{c}\text { Per day diver- } \\
\text { gence rate }\end{array}$ & $-0.84 \pm 0.05$ & $0.90 \pm 0.08$ & $1.38 \pm 0.10$ & $1.23 \pm 0.14$ \\
\hline
\end{tabular}


hatching. The divergence rate was defined as the difference in the distance between the needles of a single pair measured on June 9 minus the distance measured on June 3. Inter-needle distances were measured at two points, two $\mathrm{cm}$ from the needle bases and at the needle tips, so there were two separate calculations of the divergence rate for each needle pair sampled. As can be seen from Table 3, the divergence rates varied among sites. For both the two-cm and tip positions, divergence rates at sites I-1 and I-2 were low in comparison with those at D-1 and D-2.

Figure 5 shows the correlations between needle elongation and increases in intertip distance of needle pairs at sites I-l (low divergence rate) and D-1 (high divergence rate). At the latter site, mortality of newly hatched larvae was much higher than at the former, and the reason for the mortality difference is apparent from our observations on the behavior of newly hatched larvae. The midge eggs, which are deposited only on newly forming pine needles, are lodged between the paired needles and cling to both of them. When the newly hatching larvae move between the paired needles toward the bundle sheath, both their dorsal and ventral surfaces must remain in contact with the needles. Larvae that hatch on narrow needles and/or on those that have a high divergence rate are unable to keep both the dorsal and ventral surfaces in contact with the needles; they become disoriented and fail to reach locus for gall initiation, a position between the needles and near the bundle sheath.

\section{Early withering of galls}

Although some of the mortality that occurs in the larval feeding period is caused by resinosis, withering of shoots or of the galls themselves are more important causes of the mortality of larvae in galls. September surveys detected high mortality from shoot withering at sites D-1 and I-2, but for the surviving shoots at the same sites, mortality from early gall withering was even more pronounced (Table 4).

The seasonal changes in numbers of larvae in surviving galls observed by Park and Hyun (1977) and Sone $(1980,1983)$ were greater than those observed by us. However, we did find high mortality from early gall withering, and between-site differences in mortality caused by early gall withering were significant. It is a densitydependent mortality factor, and we believe that it is important in the natural suppression of the midge that occurs following a period of severe damage.

\section{Parasitization by Procto trupoid wasps}

Although four species of Platygastridae (Hymenoptera : Proctotrupoidea) are

Table 4. Percent larval mortality caused by early gall withering.

\begin{tabular}{cccc}
\hline Sites & $\begin{array}{c}\text { On shoots that } \\
\text { withered entirely }\end{array}$ & $\begin{array}{c}\text { On shoots } \\
\text { that survived }\end{array}$ & Total \\
\hline I -1 & $1.2 \%$ & $14.7 \%$ & $15.7 \%$ \\
I -2 & $17.3 \%$ & $46.1 \%$ & $55.4 \%$ \\
D-1 & $25.7 \%$ & $70.2 \%$ & $77.9 \%$ \\
D-2 & $0.9 \%$ & $11.9 \%$ & $12.7 \%$ \\
\hline
\end{tabular}


Table 5. Percentages of midge larvae parasitized by P. matsutama and I. seoulis.

\begin{tabular}{ccccc}
\hline \multirow{2}{*}{ Site } & \multicolumn{2}{c}{ Platygaster } & matsutama & \multicolumn{2}{c}{ Inostemma seoulis } \\
\cline { 2 - 5 } & 1983 & 1984 & 1983 & 1984 \\
\hline I -1 & $0.4 \%$ & $0.4 \%$ & $0.7 \%$ & $0.2 \%$ \\
I -2 & $1.5 \%$ & $3.5 \%$ & $0.5 \%$ & $1.7 \%$ \\
D - 1 & $17.2 \%$ & $36.2 \%$ & $0.1 \%$ & $1.9 \%$ \\
D-2 & $31.4 \%$ & $31.7 \%$ & $0.4 \%$ & $0.9 \%$ \\
\hline
\end{tabular}

known as larval or egg-larval endoparasites of the pine gall midge, only two of them, Inostemma seoulis (Ko) and Platygaster matsutama Yoshida et Hirashima, occur in Ch'ungch'ongnam-do, where this research was carried out. Parasitization by $P$. matsutama was important at sites D-1 and D-2, but parasitization by I. seoulis was negligible at all sites (Table. 5). At site D-1, parasitization by P.matsutama jumped from $17.2 \%$ in 1983 (surveyed in early April, 1984) to $32.6 \%$ in 1984, which is typical of the parasite increases that occur following peak severity of damage.

Although the parasite females oviposit into the eggs or newly hatched larvae of the host, the parasites do not kill the host larva until the spring of following year.

\section{Survivorship}

The 1984 survivorship trends for the four study sites are shown in Fig. 6. Mortality differences relating to the state of infestation progress are evident for larvae or pupae in the soil, larvae in galls, and newly hatched larvae.

From Fig. 6, it is evident that springtime larval densities in the soil were high at sites I-2 and D-1, where the percentages of gall-bearing needles were high. At sites I-1 and I-2, which had increasing population densities, survivorship for larvae and pupae in the soil was $62.5 \%$ and $62.7 \%$, respectively, relatively high in comparison to figures of $47.8 \%$ for site D-1 and $32.7 \%$ for site D-2 (Table 6). Mortalities during the larval and pupal periods were density independent, as had been found by Sone (1983), but were lower than mortalities found by Sone (1981 and 1983) or Park and Hyun (1977). The major causes of mortality during this period were Proctotrupoid wasps (cf. Sone, 1983) and soil moisture deficiency (cf. Park and Hyun, 1977).

The effects of soil moisture deficiency were not directly analyzed in this study, but

Table 6. Survivorship during the part of the larval/pupal development period between April 1 (1984) and adult emergence.

\begin{tabular}{|c|c|c|c|c|c|}
\hline \multirow{3}{*}{ Site } & \multicolumn{4}{|c|}{ No. individuals per $100 \mathrm{~cm}$ of soil surface } & \multirow{3}{*}{$\begin{array}{c}\text { Percent } \\
\text { survivorship* }\end{array}$} \\
\hline & \multicolumn{3}{|c|}{ Larvae and pupae } & \multirow{2}{*}{ Adults } & \\
\hline & Apr. 1 & Apr. 18 & May I & & \\
\hline I -1 & 57.89 & 55.92 & 46.79 & 36.20 & 62.5 \\
\hline I -2 & 155.73 & 136.10 & 128.52 & 97.64 & 62.7 \\
\hline D - 1 & 110.11 & 69.21 & 61.54 & 52.67 & 47.8 \\
\hline $\mathrm{D}-\mathrm{Z}$ & 49.15 & 31.33 & 22.45 & 16.08 & 32.7 \\
\hline
\end{tabular}

*Column 4/column 2 X 100. 
Park and Hyun (1977) found that it was a major mortality factor. Therefore, the major part of mortality of larvae and pupae in soil that was not caused by parasites probably resulted from soil moisture deficiency. For site D-2, mortality of larvae and pupae in the soil was $72 \%, 32 \%$ being contributed by parasites, and for site D-1, the total was $52 \%$, with $17.3 \%$ being contributed by parasites.

For the immature midge stages in the tree crowns, the between-site differences in survivorship trends shown in Table 8 and Fig. 6 are obvious. Those differences are attributable both to mortality of larvae within galls (early gall withering and otherwise) and to mortality of newly hatched larvae. Mortality of newly hatched larvae was higher than mortality in any of the other developmental periods and was separable into two categories : that resulting from failure to induce gall formation and that attributable to other causes. Varying in accordance with infestation progress, mortality of newly hatched larvae ranged from $76 \%$ to $85 \%$ at sites with decreasing (D-1) or stabilized populations (D-2), but was much lower at sites where population densities were increasing. The shapes of the survivorship curves (Fig. 6) reflect the differences quite effectively.

For sites D-1 and D-2, where the population density had fallen to low levels, the steep incline of the June-July segment of the curve reflects heavy mortality of newly hatched larvae. For site D-l, the June-July segment of the curve is less steeply inclined, but at site D-1 mortality of larvae in galls was higher than that at site D-2 ; as a consequence, the July-October segments of the curve are much more sharply inclined than those of site D-2 curve, with the result that the populations at both sites were at nearly identical densities during the overwintering period. The curve for site D-2 compares well with those of Sone $(1980,1983)$.

Whereas the inclination of the curve for site I-2 is rather similar to that of site D-1

Table 7. Mean number of eggs per egg cluster and their viability.

\begin{tabular}{ccc}
\hline Site & $\begin{array}{c}\text { No. eggs per } \\
\text { egg cluster (SE) }\end{array}$ & Viability(\%) \\
\hline I -1 & $7.33 \mathrm{k} 0.25$ & 98.3 \\
I -2 & $7.78 \pm 0.28$ & 99.0 \\
D -1 & $8.22 \pm 0.27$ & 94.7 \\
D-2 & $7.82 \pm 0.26$ & 96.8 \\
\hline
\end{tabular}

Table 8. Survival from the egg stage through gall formation.

\begin{tabular}{cccccccc}
\hline \multirow{2}{*}{ Site } & \multicolumn{3}{c}{ Gall formation } & & Numbers per needle pair & \multirow{2}{*}{$\begin{array}{l}\text { Total } \\
\text { survival* }\end{array}$} \\
\cline { 2 - 3 } & NE & NG & Percent & & eggs & larvae & \\
\hline I -1 & 494 & 389 & 79 & & 7.33 & $5.75 \mathrm{k} 0.42$ & 62 \\
I -2 & 960 & 827 & 86 & & 7.78 & $4.80 \pm 0.32$ & 53 \\
D - 1 & 263 & 142 & 54 & & 8.22 & $3.62 \pm 0.25$ & 24 \\
D - 2 & 125 & 45 & 36 & & 7.82 & $3.26 \mathrm{k} 0.28$ & 15 \\
\hline
\end{tabular}

$\mathrm{NE}=$ Number of egg-bearing needle pairs examined.

$\mathrm{NG}=$ Number of needle pairs on which galls formed.

* (NG x no. larvae) $\times 100 /(\mathrm{NE} \times$ no. eggs $)$. 
for the June-July segment, the latter is much steeper over the July-October segments, but the incline of the curve for site I-1 is not steep for either the June-July or JulyOctober segments. It therefore seems apparent that the major statistic distinguishing decreasing populations from increasing ones is high mortality of newly hatched larvae, or both newly hatched larvae and larvae in galls. We believe, therefore, that it is mortality during those portions of larval development that reduces $T$. japonensis populations, stabilizes them at low densities, and enables stands of Pinus densiflora to recover.

Viability of eggs ranged from $94.7 \%$ to $99 \%$ (Table 7), so mortality in the egg stage was relatively low. Those figures compare well with the findings of Jeon (1984) and Sone (1980) but are higher than the viability rates found by Park and Hyun (1977).

\section{Conclusion}

In Korea, $T$. japonensis has been continually expanding its range to areas in which it did not occur previously. Severe damage to the infested pine trees has been essentially confined to the frontal zone of range expansion. Following initial establishment of the midge in forests of red pine, population levels rise for six consecutive years and then decline to low levels over a period of about 6 more years (Park and Hyun, 1983) as a result of increasing mortality in the larval stage,

Differing kinds of mortality factors operate in different periods of midge larval development. For newly hatched larvae the mortality factors are unfavorable morphological and physiological conditions of most needles ; they are narrowness and consequent flexibility of the needles and high rates of needle divergence in early June. For larvae in galls, the mortality factors are early gall withering, withering of the entire shoot or tree, or intraspecific competition for food. The larval mortality that occurs prior to the time when the midge larvae emerge from their galls and drop to the soil is largely resultant from the decrease in host vigor caused by heavy midge infestations ; it is therefore strongly density dependent. The mortality factors effecting larvae that have dropped from-the needles to the soil are soil moisture deficiency, Proctotrupoid parasites that had attacked the midge eggs or first instars, and sundry predators.

\section{References}

Jeon, M. J., 1983. On the instar crimination of the larva of pine needle gall midge, Thecodiplosis japonensis and the appearance period of each instar. Korean J.Ent.,13(1): 43-46. (In Korean with English summary)

Jeon, M. J., Z. Kuranaga and I. Ogouchi, 1982. [Studies on the biology of pine needle gall midge, Thecodiplosis japonensis $(X)$. Sex ratio and number of ovarian eggs of the midge and its parasites.] Bull. Kyushu Branch Jap. For. Soc., 35: 155-156. (In Japanese).

Ko, J. H., 1965. Studies on the Isostasius seoulis (sp. nov.), the larval parasite of the pine gall midge (Thecodiplosis japonensis Uchida et Inouye), taxonomical and morphological studies. Res. Rep. 0. R. D., 8(2) : 91-96. (In Korean with English summary) 
- 1982. The pine gall midge (Thecodiplosis japonensis) in Korea. Proc. Korea-U. S. A. Jt. Sem. For. Dis. Ins. Pests, 41-53.

Miura, T., 1962. Studies on Thecodiplosis japonensis Uchida et Inouye and its important parasite, Platygaster sp. 168 pp. +18 pls. For. Exp. St. Shimane Pref., Matsue. (In Japanese with English summary)

Park, K. N. and J. S. Hyun, 1977. Studies on the population dynamics of pine needle gall midge, Thecodiplosis japonensis Uchida et Inouye. Res. Rep. For. Res. Ins., 24 : 91-107. (In Korean with English summary)

— and — 1983. Studies on the effects of the pine needle gall midge, Thecodiplosis japonensis Uchida et Inouye, on the growth of the red pine, Pinus densiflora Siebold et Zuccarini (I) -Changes of gall formation rate-. J. Korean For. Soc., 61: 20-26. (In Korean with English summary)

— and - 1983. Ditto, (II)-Growth impact on red pine-. Ibid., 62: 87-95. (In Korean with English summary)

Sone, K., 1980. Seasonal changes in the population of the pine needle gall midge, Thecodiplosis japonensis Uchida et Inouye (Diptera : Cecidomyiidae). J. Jap. For. Soc., 62 : 168-175. (In Japanese with English summary)

- and H. Takeda, 1983. Studies on the distribution pattern of the pine needle gall midge, Thecodiplosis japonensis Uchida et Inouye (Diptera: Cecidomyiidae) in a pine forest. Res. Popul. Ecol., 25, : 336-352.

Takafuji, A., 1976. Studies on the ecology of the Japanese cedar gall midge, Contarinia inouyei Mani (Diptera : Cecidomyiidae). Kontyâ, 44 : 554-569. (In Japanese with English summary)

Varley, G. C. 1947. The natural control of population balance in the knapweed gall-fly (Urophora jaceana). J. Anim. Ecol., 16: 139-187.

Yoshida, N., Z. Kuranaga and K. Morimoto, 1973. '[Life table of the Japanese cedar gall midge, Contarinia inouyei, and the pine gall midge, Thecodiplosis japonensis.] Trans. 84th Ann. Meet. Jap. For. Soc.: 344-345. (In Japanese)

— and Y. Hirashima, 1979. Systematic studies on Proctotrupoid and Chalcidoid parasites of gall midges injurious to Pinus and Cryptomeria in Japan and Korea (Hymenoptera). Esakia, (14) :113133. 